JURNAL ILMIAH MUQODDIMAH

Jurnal IImu Sosial, Politik, dan Humaniora

\title{
DAMPAK SOCIAL DISTANCING TERHADAP KESEJAHTERAAN PEDAGANG DI PASAR TRADISIONAL KARTASURA PADA ERA PANDEMI KORONA
}

\author{
Christina Purbawati ${ }^{1}$, Lathifah Nurul Hidayah ${ }^{2}$, Markhamah $^{3}$ \\ Program Studi Magister Pendidikan Bahasa Indonesia, \\ Universitas Muhammadiyah Surakarta \\ s200190005@student.ums.ac.id ${ }^{1}$ \\ s200190003@student.ums.ac.id ${ }^{2}$ \\ mar274@ums.ac.id ${ }^{3}$
}

\begin{abstract}
Abstrak
Pandemi korona yang sekarang ini terjadi menjadi momok bagi masyarakat, khususnya bagi para pedagang. Peraturan pemerintah yang mengharuskan masyarakat melakukan pembatasan sosial (sosial distancing) membuat para pedagang terhambat dalam proses perdagangan. Penelitian ini bertujuan (1) mengidentifikasi dampak yang ditimbulkan akibat adanya pembatasan sosial (social distancing) bagi pedagang dan (2) langkah yang diambil para pedagang pada era pandemi corona. Pendekatan penelitian ini adalah deskriptif kualitatif. Data penelitian ini adalah dampak adanya social distancing bagi para pedagang di Pasar Tradisional Kartasura. Sumber data berasal dari beberapa pedagang yang berjualan di pasar, seperti pedagang sayur, pedagang buah, pedagang daging, dan pedagang bahan pokok lainnya yang berjumlah 20 responden. Pengumpulan data pada penelitian ini menggunakan teknik wawancara, rekam, dan dilanjutkan catat. Analisis data pada penelitian ini menggunakan metode interaktif melalui tiga tahap yakni reduksi data, sajian data, dan penarikan simpulan. Hasil penelitian menunjukkan (1) dampak yang ditimbulkan akibat adanya pembatasan sosial (social distancing) bagi pedagang di Pasar Tradisional Kartasura yakni pasar menjadi sepi, daya beli masyarakat menurun, dan distribusi bahan yang terhambat; (2) langkah-langkah yang diambil para pedagang di Pasar Tradisional Kartasura pada era pandemi corona yakni mengurangi jumlah dagangannya, menurunkan harga, dan beralih profesi.
\end{abstract}

Kata kunci: pandemi korona, pedagang, covid-19

\begin{abstract}
Corona pandemic which is now happening is a scourge for the community, especially for traders. Government regulations that require people to limit their distance (social distancing) make traders hampered in the trading process. This study aims to (1) identify the impact caused by social distancing for traders and (2) steps taken by traders during the corona pandemic era. The approach of this study is descriptive qualitative. The data of this study is the impact of social distancing for traders in Kartasura Traditional Market. The sources of data came from several traders who sell at the market, such as vegetable traders, fruit traders, meat traders, and other staple traders, totaling 20 respondents. Collecting data in this study used interview techniques, records, and continued notes. Data analysis in this study used an interactive method through three stages namely data reduction, data display, and drawing conclusions. The results showed (1) the impact caused by social distancing for traders in Kartasura Traditional Market, which is the market being quiet, the people's purchasing power is decreasing, and the distribution of materials is hampered; (2) steps taken by traders in Kartasura Traditional Market during the corona pandemic era, namely reducing the amount of merchandise, lowering prices, and switching professions.
\end{abstract}

Keywords: corona pandemic, trader, covid-19 


\section{PENDAHULUAN}

Para pedagang di Pasar Tradisional Kartasura menjerit karena maraknya wabah virus korona. Virus korona merupakan pandemi yang mudah menyebar secara contagious (Mona, 2020). Kasus virus korona yang merupakan pandemi global menimbulkan kekhawatiran dari berbagai kalangan, khususnya masyarakat. Kehawatiran masyarakat semakin terasa melihat jumlah lonjakan pasien positif korona setiap harinya. Melihat tingkat persebaran virus korona yang cukup tinggi, mengharuskan pemerintah untuk segera mengambil langkah strategis (Ristyawati, 2020). Sejumlah kebijakan diambil oleh pemerintah untuk pencegah penyebaran virus korona. Beberapa diantaranya menutup taman bermain, tempat wisata, meliburkan kegiatan belajar mengajar di sekolah, dan melarang warga berkerumun atau yang tren sekarang ini disebut dengan social distancing. Social distancing merupakan cara tepat dalam menangani wabah dan itulah yang dijalankan oleh nabi tatkala wabah menjangkiti kota Madinah (Rajab et.al, 2020). Social distancing diterapkan oleh pemerintah dalam rangka membatasi interaksi manusia dan menghindarkan masyarakat dari kerumunan agar terhindar dari penyebaran covid-19 (Syarifudin, 2020). Adapun kebijakan yang berkaitan dengan pembatasan sosial yang dipilih Presiden Jokowi dalam Konferensi Pers yang dilakukan pada tanggal 31 Maret 2020 dalam menyikapi pandemi korona di Indonesia yakni Undang-Undang Nomor 6 Tahun 2018 tentang Kekarantinaan Kesehatan. Pengaruh yang paling dirasakan oleh pedagang di pasar tradisional Kartasura adalah pemberlakuannya kebijakan social distancing yang dikeluarkan oleh Pemerintah Indonesia. Akibatnya beberapa pedagang kebingungan dan pemasukan terancam defisit parah. Kebijakan pembatasan sosial yang dipilih dengan pertimbangan ekonomi masyarakat bukan berarti tidak ada masalah. Social distancing tetap berdampak pada perekonomian masyarakat. Salah satu kalangan masyarakat yang terdampak adalah pedagang kecil di pasar tradisional Kartasura. Pedagang kecil yang begitu melekat dengan slogan "hari ini untuk hari besok", maksudnya kebutuhan mereka besok terpenuhi jika kerja hari ini. Ketika mereka tidak bekerja hari ini, maka mereka tidak akan bisa memenuhi kebutuhan untuk besok.

Meskipun para pedagang tetap berjualan ditengah anjuran pemerintah untuk social distancing, hal itu bukan berarti tak mengandung celah masalah. Apabila tidak berkerja akibatnya adalah tidak bisa muncukupi kebutuhan. Pendapatan mereka mengalami penurunan diakibatkan oleh sepinya orang untuk berkeliaran keluar rumah. $\mathrm{Hal}$ itu dialami oleh pedagang sayuran, pedagang buah, pedagang cabai, dan pedagang lainnya di pasar tradisional Kartasura. Selain itu, mereka tidak mendapatkan jaminan sosial dari pekerjaan mereka sendiri. Sakit akan menjadi tanggungan sendiri bagi mereka. Seperti yang diungkapkan dalam penelitian Armiani (2020) bahwa saat ini dunia sedang dilanda krisis kesehatan akibat penularan covid-19 atau corona virus disease. Hal ini kemudian menjadi dasar mengapa pedagang rentan di tengah wabah covid19.

Coronavirus adalah sekumpulan virus dari Subfamili Orthocronavirinae dalam keluarga Coronaviridae dan Ordo Nidovirales (Yunus, 2020). Pada era pandemi coronavirus saat ini, masyarakat dituntut untuk mengurangi aktivitas di luar rumah yang mempengaruhi ekonomi para pedagang. Ekonomi merupakan faktor penting di kehidupan manusia. Kehidupan keseharian manusia dapat dipastikan selalu bersinggungan dengan kebutuhan ekonomi (Honoatubun, 2020). Para pedagang kecil di pasar tradisional Kartasura mengalami kerugian pesat dengan adanya wabah covid-19 ini. Pembatasan aktivitas akibat pandemi covid-19 telah menimbulkan kerugian ekonomi secara nasional (Hadiwardoyo, 2020). ILO memperkirakan bahwa covid19 akan merampas penghidupan dari 
195 juta pekerja penuh-waktu di seluruh dunia (ILO 2020).

Permasalahan yang dialami oleh pedagang di pasar tradisional Kartasura mengharuskan pemerintah perlu mengetahuinya. Kebijakan social distancing pun juga berdampak kepada memburuknya perekonomian masyarakat salah satunya perekonomian para pedagang kecil. Mereka perlu dipertimbangkan untuk menjadikan sasaran bantuan oleh pemerintah di masa wabah covid-19. Kondisi ini sangat penting untuk mendapatkan perhatian karena sangat rentan dengan penyebaran wabah covid19 yang akhir-akhir ini menimbulkan keresahan seluruh lapisan masyarakat (Sulaeman, 2020).

Harapan dari penelitian ini yaitu apabila pemerintah mengeluarkan kebijakan mengenai pembatasan sosial (social distancing) yaitu Undang-Undang Nomor 6 Tahun 2018 tentang Kekarantinaan Kesehatan yang berdampak ke aspek lain, maka perlu kebijakan pendukung aspek lain tersebut. Seperti yang tegas diungkapkan pada pembukaan UndangUndang Dasar 1945 bahwa negara Indonesia dibentuk untuk melindungi segenap bangsa, memajukan kesejahteraan umum dan mencerdaskan kehidupan bangsa (Sulistiawati, 2012). Selain itu, perlu adanya pembangunan pada bidang ekonomi bagi pedagang kecil yaitu dengan pemerintah mengupayakan kesejahteraan bagi para pedagang dan perlindungan di tengah wabah pandemi korona saat ini. Hal tesebut akan menjadi penguat bagi pedagang kecil yang tetap bekerja saat musim corona. Sulistiawati (2012) dalam penelitiannya menjelaskan pembangunan di bidang ekonomi ditujukan untuk menjawab berbagai permasalahan dan tantangan dengan tujuan akhir adalah meningkatkan kesejahteraan masyarakat.

$$
\text { Masyarakat }
$$

merupakan sekelompok manusia yang saling berinteraksi sehingga dalam masyarakat terdapat kesepakatan agar ditaati dan dilaksanakan oleh setiap anggota masyarakat (Dura, 2016). Dengan adanya fenomena covid-19 ini, masyarakat Indonesia memberlakukan kesepakatan untuk menjaga jarak atau social distancing guna meminimalkan terjangkitnya virus corona ini. Namun, social distancing membuat dampak baru pagi pedagang kecil di pasar tradisional Kartasura. Adapun hasil penelitian terdahulu yang dilakukan oleh (Ristyawati, 2020) mengemukakan bahwa kebijakan yang diambil pemerintah harus dapat menjamin terutama kepada kaum menengah ke bawah mampu memenuhi kebutuhannya untuk menjamin hak atas hidup masyarakatnya dan tidak terkurangi suatu apapun harkat martabat masyarakatnya (sesuai amanat UUD NRI Tahun 1945). Penelitian serupa juga dilakukan oleh (Handayanto dan Herlawati, 2020) yang mengemukakan bahwa dalam mengatasi wabah covid-19 pemerintah menggunakan kebijakan Pembatasan Sosial Berskala Besar (PSBB). Banyak pihak yang mendukung dan juga kurang setuju dengan PSBB, namun demi perekonomian tetap berjalan dan wabah dapat diatasi, pemerintah tidak mengambil kebijakan karantina wilayah.

Penelitian yang sama juga dilakukan oleh (Kresna \& Ahyar, 2020). Persamaan penelitian yang dilakukan oleh (Kresna \& Ahyar, 2020) dengan penelitian ini yakni objek kajiannya meneliti mengenai pengaruh atau dampak social distancing. Hasil penelitian (Kresna \& Ahyar, 2020) menunjukkan bahwa masyarakat perlu memperhatian penerapan protokol kesehatan dan upaya untuk menjaga dari penyebaran virus korona. Penelitian serupa juga dilakukan oleh (Pradana \& Casman, 2020). Persamaan penelitian (Pradana \& Casman, 2020) dengan penelitian ini yakni objek kajiannya fokus pada pengaruh kebijakan social distancing di tengah pandemi korona. Hasil penelitian (Pradana \& Casman, 2020) mengemukakan bahwa pada fase pandemi seperti sekarang ini, masyarakat membutuhkan diterapkannya social distancing untuk 
meminimalisasi penyebaran wabah virus korona.

Berdasarkan latar belakang tersebut, peneliti terdorong untuk melakukan penelitian guna mengidentifikasi dampak apa saja yang dialami para pedagang di Pasar Tradisional Kartasura akibat adanya pembatasan sosial (social distancing) dan langkah apa yang telah diambil para pedagang dalam menyikapi wabah covid-19 yang telah berlangsung lebih dari satu bulan ini.

\section{METODE}

Penelitian ini adalah deskriptif kualitatif (Tojo \& Takagi, 2017) Deskriptif kualitatif dalam penelitian ini digunakan untuk menghasilkan data deskripsi yakni dampak yang ditimbulkan akibat adanya pembatasan sosial (social distancing) bagi pedagang dan langkah yang diambil para pedagang pada era pandemi corona. Data penelitian ini adalah dampak adanya social distancing bagi para pedagang di Pasar Tradisional Kartasura. Sumber datanya berasal dari beberapa pedagang yang berjualan di pasar, seperti pedagang sayur, pedagang buah, pedagang daging, pedagang cabai, pedagang tomat, pedagang kolang-kaling, pedagang laukpauk dan pedagang bahan pokok lainnya sejumlah 20 orang. Pengumpulan data pada penelitian ini menggunakan teknik wawancara, rekam, dan dilanjutkan catat. Analisis data pada penelitian ini menggunakan metode interaktif.

Analisis data dengan model interaktif dilakukan melalui tiga tahap yaitu: reduksi data, sajian data, dan penarikan simpulan. Reduksi data dilakukan dengan cara menyeleksi data yang difokuskan pada dampak social distancing bagi pedagang di Pasar Tradisional Kartasura. Sajian data dalam penelitian ini berupa deskripsi temuan tentang dampak pembatasan sosial (social distancing) terhadap pedagang di Pasar Tradisional Kartasura dan langkah apa saja yang telah diambil para pedagang dalam menyikapi wabah covid-19 yang telah berlangsung lebih dari satu bulan ini. Lebih lanjut data tersebut disajikan dalam bentuk deskripsi data yang kemudian dianalisis dan dikaji didasarkan pada teori yang mendasari. Penarikan simpulan dilakukan setelah melalui reduksi data hasil temuan. Selanjutnya, dilakukan verifikasi dan penarikan simpulan. Namun, jika dalam penarikan simpulan masih dinilai belum signifikan, dilakukan verifikasi dengan cara menelusuri ulang mulai dari reduksi data serta sajian datanya, dengan demikian hal ini merupakan suatu siklus. Bentuk interaksi dari komponen reduksi data, sajian data, penarikan simpulan, dan verifikasi ini dilakukan sebagai proses analisis tersebut. Proses siklus simpulan komponen-komponen tersebut dilakukan oleh peneliti sejak awal pengumpulan data bahkan sejak penelitian ini dimulai hingga penarikan simpulan yang meyakinkan.

\section{HASIL DAN PEMBAHASAN}

Hasil dan pembahasan penelitian ini fokus pada dampak yang ditimbulkan akibat adanya pembatasan sosial (social distancing) bagi pedagang dan langkah yang diambil para pedagang pada era pandemi korona saat ini. Berikut ini hasil dan pembahasan. Dampak Pembatasan Sosial (Social
Distancing) bagi Pedagang

Covid-19 merupakan penyakit menular yang disebabkan oleh coronavirus (Abdussomad, 2020). Dampak yang ditimbulkan akibat adanya wabah covid-19 ternyata tidak hanya menyerang buruh-buruh pabrik saja yang dirumahkan atau para pengemudi ojek online yang kehilangan banyak penumpang, melainkan berdampak pula pada para pedagang buah, sayur, daging, dan bahan pokok lainnya yang kesehariannya berjualan di pasar. Pasar merupakan tempat pertemuan antara penjual dan pembeli (Indrawati, 2014). Maraknya virus korona menyebabkan para pekerja di pasar terganggu khususnya para pedagang di Pasar Kartasura. Dengan demikian, covid-19 memberikan dampak buruk terhadap perekonomian masyarakat di Indonesia (Hanoatubun, 2020). Berdasarkan penelitian, ada tiga dampak yang 
dirasakan para pedagang di Pasar Kartasura.

\section{Pasar Menjadi Sepi}

Berdasarkan hasil wawancara dengan pedagang yang berjualan di dalam maupun luar Pasar Tradisional Kartasura, mereka menuturkan jika adanya wabah covid-19 membuat para pedagang menjadi sepi pembeli. Seperti yang diungkapkan oleh pedagang ketela yang berjualan diluar pasar, jika jumlah pembeli dagangannya berkurang semenjak adanya pembatasan sosial. Hal yang sama juga diungkapkan oleh penjual kolang-kaling yang setiap harinya berjualan di dalam pasar, jika kondisi pasar menjadi sepi karena banyak penjual yang memilih tidak berjualan ditambah lagi jumlah pembeli yang banyak berkurang.

la juga menuturkan jika sehabis dhuhur, ia sudah menutup dagangannya dan kembali ke rumah. Penjual bahan pokok seperti beras, minyak, telur, gula batu, dan lain sebagainya menambahkan jika kondisi pasar yang sepi juga membuat ia menutup dagangannya lebih awal. Sebelum adanya wabah covid-19, ia menuturkan jika biasa menutup dagangannya pukul 5 sore.

Namun, karena adanya wabah covid-19 yang membuat kondisi pasar sepi, membuat ia menutup dagangannya pukul 3 sore. Pernyataan dari beberapa pedagang tersebut juga diiyakan oleh pedagang lain seperti pedagang cabai, tomat, sayur-sayuran, pisang, jagung, lauk-pauk maupun pedagang bayam yang juga merasa kondisi pasar menjadi sepi pembeli akibat adanya pembatasan sosial di masa pandemi korona ini.

\section{Daya Beli Masyarakat Menurun}

Adanya pembatasan sosial juga mempengaruhi penurunan daya beli masyarakat. Diungkapkan oleh (Hanoatubun, 2020) bahwa tingginya laju inflasi dapat mempengaruhi daya beli masyarakat khususnya golongan berpendapatan rendah. Akan tetapi, adanya wabah covid-19 di Indonesia ternyata juga mampu mempengaruhi daya beli masyarakat di Pasar Tradisional Kartasura.
Hal tersebut nampak dari keluhan para pedagang di Pasar Tradisional Kartasura, seperti pedagang sayur-sayuran, bahan pokok, ayam, dan pisang. Pedagang sayuran mengungkapkan jika pembatasan sosial (social distancing) pada masa pandemi korona ini mempengaruhi jumlah barang dagangan yang dibeli oleh pelanggan. Ini dikarenakan banyaknya rumah makan seperti bebek goreng yang tutup. Padahal seperti yang banyak orang ketahui bahwa jumlah rumah makan bebek goreng yang ada di wilayah Kartasura tak terhitung karena begitu banyaknya.

Pedagang tersebut menambahkan jika warung makan bebek goreng yang biasanya berbelanja kol sekitar $25 \mathrm{~kg}$ sampai $30 \mathrm{~kg}$, sekarang hanya berbelanja $5 \mathrm{~kg}$ saja. la pun hanya bisa pasrah dengan keadaan ini karena bukan hanya ia saja yang mengalaminya tetapi dampaknya juga dirasakan semua pedagang. Hal yang sama juga diungkapkan oleh pedagang bahan pokok yang merasa kehilangan banyak pembeli. la menuturkan jika adanya wabah covid-19 membuat pemerintah melarang adanya acara besar seperti hajatan sehingga berpengaruh pada pembeli dagangannya.

Hal tersebut juga diiyakan oleh penjual ayam potong yang juga terkena dampak akibat dilarangnya penyelenggaraan acara hajatan sehingga berpengaruh pada penjualannya. Pedagang pisang pun juga mengeluhkan adanya pembatasan sosial mempengaruhi penjualannya karena banyak pembeli langganannya yang libur sehingga pemasukan yang diperolehnya berkurang. Pedagang makanan siap saji seperti pedagang kaki lima angkringan atau HIK yang juga menuturkan mengalami penurunan pembeli sebanyak 50 persen karena adanya aturan pemerintah daerah di tengah masa pandemi korona untuk mengemasi dagangannya apabila jam sudah menunjukkan pukul 9 malam.

$$
\text { Pedagang Kaki Lima atau }
$$

disingkat $\mathrm{PKL}$ adalah istilah untuk menyebut penjaja dagangan yang 
menggunakan gerobak (Wafirotin, 2015).

\section{Distribusi Bahan Terhambat}

Perkembangan ekonomi di dunia yang membawah pada konsekuensi terhadap peningkatan aktivitas perdagangan (Sambur, 2015). Diungkapkan oleh salah seorang pedagang kolang-kaling bahwa akibat adanya pembatasan sosial (social distancing) pada masa pandemi corona ini, selain kondisi pasar yang sepi karena penurunan jumlah pembeli secara signifikan, pasokan barang dagangannya juga mengalami keterlambatan sehingga ia hanya bisa menjual bahan makanan seadanya saja.

la menambahkan jika sebelum adanya wabah covid-19, pasokan barang dagangannya selalu banyak atau melimpah. Namun, semenjak adanya wabah tersebut, ia harus rela menjual bahan makanan yang masih tersisa saja sembari menunggu bahan makanan yang baru dating. Hal yang sama juga dialami oleh beberapa pedagang sayur yang berjualan di lantai 2 Pasar Tradisional Kartasura yang terkadang hanya menjual sedikit sayur-sayuran karena pasokan sayuran yang sedikit.

\section{Langkah yang Diambil Pedagang pada Masa Pandemi Corona}

Wabah covid-19 yang sudah berlangsung selama beberapa bulan dan belum berakhir sampai saat ini ternyata membuat para pedagang di Pasar Kartasura memutar otak agar tetap bisa mencari rezeki untuk memenuhi kebutuhan rumah tangganya di tengah wabah yang melanda negeri ini. Berikut ada tiga langkah yang diambil pedagang pada era pandemi korona.

\section{Mengurangi Jumlah Dagangan}

Banyak dari pedagang di Pasar Kartasura mengurangi jumlah barang dagangannya di tengah pandemi korona ini. Seperti yang diungkapkan oleh pedagang ketela yang mengurangi jumlah ketela yang dijualnya. la mengatakan bahwa "tak apa berjualan sedikit-sedikit asalkan setiap hari pergi ke pasar daripada hanya berdiam diri di rumah".

Hal yang sama juga dilakukan oleh pedagang ayam potong yang hanya menjual sekitar 10 sampai 15 ekor ayam saja setiap harinya pada masa pandemi corona ini. Hal ini tentu berbeda jauh dengan penjualan sebelum adanya wabah covid-19. la berkata bahwa "saat ini lebih baik berjualan sedikit-sedikit asalkan habis daripada berjualan banyak tetapi tidak laku sama sekali”. Penjual sayur-sayuran seperti kol dan wortel pun juga menuturkan jika adanya wabah covid-19 membuat ia mengurangi berbelanja sayurannya.

Pedagang tersebut mengatakan "sebelum adanya wabah covid-19, saya biasanya berbelanja kol sampai 1 kwintal atau $100 \mathrm{~kg}$. Namun karena wabah covid-19, saya hanya berbelanja kol sekitar $45 \mathrm{~kg}$ sampai $50 \mathrm{~kg}$ saja. Itu pun juga tidak habis terjual". Selain itu, ia yang biasanya berbelanja wortel sampai $20 \mathrm{~kg}$, sekarang ini hanya mampu membeli sekitar $10 \mathrm{~kg}$ saja dikarenakan tempat makan yang setiap harinya berbelanja di penjual sayuran tersebut seperti warung steak libur total semenjak pertama adanya wabah covid-19 sampai saat ini. la juga mengungkapkan jika suaminya yang bekerja di SPBU juga banyak libur karena pasokan BBM yang jumlahnya tidak banyak.

\section{Menurunkan Harga}

Langkah selanjutnya yang ditempuh oleh para pedagang di Pasar Kartasura, yaitu menurunkan harga barang dagangannya. Seperti yang dilakukan oleh pedagang ayam potong. la mengungkapkan jika sebelum adanya wabah covid-19, harga ayam potong berkisar di harga 30 ribu rupiah. Namun, saat ini hanya berkisar pada harga 28 ribu rupiah. Hal yang sama juga terjadi pada pedagang pisang.

Dampak adanya wabah covid-19 seolah-olah membuat pedagang pisang menjerit karena harga jual dagangannya. Salah seorang pedagang mengungkapkan jika harga 2 tangkap pisang yang biasanya berkisar antara 125 ribu sampai 150 ribu rupiah, saat ini hanya berkisar di harga 65 ribu sampai 70 ribu rupiah saja dikarenakan pembelinya tidak ada. Penyebabnya yaitu adanya pemberlakuan larangan pengadaan acara yang mengundang banyak orang seperti acara hajatan atau 
acara slametan. la juga menambahkan jika harga pisang mengalami penurunan dikarenakan dari agennya, harga pisang tersebut memang dijual murah.

Pedagang cabai pun juga mengalami hal yang sama. Cabai rawit yang dulu harganya meroket tajam, saat ini dijual berkisar pada harga 15 ribu rupiah per kilonya. Pedagang tersebut menuturkan jika harga cabai yang murah dikarenakan para petani cabai menjualnya juga dengan harga yang murah. Hal ini tentu merugikan para petani cabai karena biaya yang dikeluarkan untuk merawat cabai hingga siap panen tidak sebanding dengan apa yang didapat.

\section{Beralih Profesi}

Dampak yang ditimbulkan akibat adanya pembatasan sosial (social distancing) ternyata juga mampu membuat seseorang beralih profesi. Diungkapkan oleh salah seorang pedagang buah pepaya di Pasar Kartasura, dampak dari wabah covid-19, membuatnya beralih profesi atau putar haluan yang awalnya pengusaha katering menjadi penjual buah. la mengatakan jika sudah satu minggu ia bersama suami menekuni berjualan pepaya di Pasar Kartasura.

la menambahkan jika ia harus berjualan buah agar tetap produktif atau menghasilkan daripada memilih hanya berdiam diri di rumah. Karena ia merasa bantuan dari pemerintah pun juga tidak ada sedangkan ia juga perlu mempersiapkan biaya tambahan untuk anak yang masih di dalam kandungan. Sang suami juga menambahkan jika mereka harus belajar lagi karena berjualan buah mengharuskan mereka merintis usaha dari awal lagi sedangkan ilmu yang mereka miliki dalam hal berdagang buah masih sedikit. Di akhir perbincangan, ia juga menuturkan lagi jika tidak apa-apa penghasilan sedikit asalkan masih cukup untuk makan.

Hasil penelitian yang telah dipaparkan tersebut relevan dengan penelitian yang dilakukan oleh (Herispon, 2020). Langkah-langkah yang diambil pedagang pada masa pandemi korona diantaranya ialah menurunkan harga. Dari hasil penelitian yang juga mengkaji dampak pembatasan sosial menunjukkan jika dampak ekonomi pandemi korona mengakibatkan terjadinya deflasi. Adanya penurunan harga yang ditunjukkan oleh turunnya indeks kelompok pengeluaran, yaitu kelompok makanan dan minuman. Hal tersebut dikarenakan adanya himbauan dari pemerintah untuk melakukan social distancing membuat warga mengurangi kegiatan di luar rumah seperti berbelanja ke pasar. Akibat tingkat konsumsi masyarakat menurun, menyebabkan para pedagang akhirnya menurunkan harga barang dagangannya.

\section{SIMPULAN DAN SARAN}

Berdasarkan hasil dan pembahasan yang telah disajikan di atas dapat disimpulkan bahwa adanya pembatasan sosial (social distancing) yang diberlakukan oleh pemerintah yang juga berlaku bagi para pedagang di Pasar Tradisional Kartasura ternyata berdampak pada kondisi pasar yang sepi pembeli, daya beli masyarakat yang menurun akibat tidak diperbolehkannya penyelenggaraan acara yang mengundang banyak orang sehingga pembeli hanya berbelanja untuk kebutuhan sehari-hari saja, dan distribusi bahan yang terhambat pengirimannya. Adapun langkah-langkah yang telah diambil para pedagang di Pasar Tradisional Kartasura agar tetap dapat berjualan setiap harinya yaitu mengurangi jumlah barang dagangannya baik itu pedagang sayur maupun pedagang daging, melakukan penurunan harga agar barang dagangannya tetap laku terjual, dan adapula yang beralih profesi yang semula pemilik katering menjadi penjual buah

Adapun langkah yang dapat ditempuh terkait dengan kondisi yang dialami para pedagang di Pasar Kartasura yakni menawarkan kepada para pedagang di Pasar Tradisional Kartasura untuk berjualan secara online. $\mathrm{Hal}$ itu efektif dilakukan ditengah pandemi korona saat ini. Namun, perlu adanya fasilitas dan pendampingan dalam berjualan online. Hal ini dikarenakan sebagian besar pedagang 
di Pasar Tradisional Kartasura sudah tidak muda lagi atau lanjut usia. Secara tidak langsung para pedagang mengalami kendala dalam menggunakan smartphone. Jadi perlu adanya pendampingan dari pihak-pihak terkait.

\section{DAFTAR PUSTAKA}

Abdusshomad, A. (2020). Pengaruh Covid-19 terhadap Penerapan Pendidikan Karakter dan Pendidikan Islam. QALAMUNA: Jurnal Pendidikan, Sosial, dan Agama, 12(2), 107-115.

Armiani, S., Fajri, S. R., Sukri, A., \& Pidiawati, B. Y. (2020). Pelatihan Pembuatan Masker sebagai Upaya Antisipasi Penyebaran Covid-19 di Desa Anyar Kabupaten Lombok Utara. Jurnal Pengabdian UNDIKMA, 1(1), 22-27.

Dura, J. (2016). Pengaruh Akuntabilitas Pengelolaan Keuangan Alokasi Dana Desa, Kebijakan Desa, dan Kelembagaan Desa terhadap Kesejahteraan Masyarakat. Jurnal Ilmiah Bisnis dan Ekonomi Asia, 10(2), 26-32.

Hadiwardoyo, W. (2020). Kerugian Ekonomi Nasional Akibat Pandemi Covid-19. BASKARA: Journal of Business \& Entrepreneurship, 2(2), 83-92.

Handayanto, R. T., \& Herlawati. (2020). Efektifitas Pembatasan Sosial Berskala Besar (PSBB) di Kota Bekasi Dalam Mengatasi COVID-19 dengan Model Susceptible-InfectedRecovered (SIR). Jurnal Kajian IImiah, 20(2), 119-124.

Hanoatubun, S. (2020). Dampak Covid-19 terhadap Prekonomian Indonesia. EduPsyCouns: Journal of Education, Psychology and Counseling, 2(1), 146-153.

Herispon. (2020). Dampak Ekonomi Pembatasan Sosial Berskala Besar terhadap Masyarakat
Kota Pekanbaru di Provinsi Riau. Eko dan Bisnis: Riau Economic and Business Review, 11(2), 164-173.

Indrawati, T., \& Yovita, I. (2014). Analisis Sumber Modal Pedagang Pasar Tradisional di Kota Pekanbaru. Jurnal Ekonomi, 22(1), 1-8.

Kresna, A., \& Ahyar, J. (2020). Pengaruh Physical Distancing dan Social Distancing terhadap Kesehatan dalam Pendekatan Linguistik. Jurnal Syntax Transformation, 1(4), 14-19.

Mona, N. (2020). Konsep Isolasi dalam Jaringan Sosial untuk Meminimalisasi Efek Contagious (Kasus Penyebaran Virus Corona di Indonesia. Jurnal Sosial Humaniora Terapan, 2(2), 117125.

Pradana, A. A., \& Casman, C. (2020). Pengaruh Kebijakan Social Distancing pada Wabah COVID-19 terhadap Kelompok Rentan di Indonesia. Jurnal Kebijakan Kesehatan Indonesia: JKKI, 9(2), 61-67.

Rajab, A. J., Nurdin, M. S., \& Mubarak, H. (2020). Tinjauan Hukum Islam pada Edaran Pemerintah dan MUI dalam Menyikapi Wabah Covid-19. BUSTANUL FUQAHA: Jurnal Bidang Hukum Islam, 1(2), 156-173.

Ristyawati, A. (2020). Efektifitas Kebijakan Pembatasan Sosial Berskala Besar Dalam Masa Pandemi Corona Virus 2019 oleh Pemerintah Sesuai Amanat UUD NRI Tahun 1945. Administrative Law \& Governance Journal, 3(2), 240249.

Sambur, N. C. P. (2015). Analisis Pengaruh Pajak Pertambahan Nilai (PPN) dan Pajak Penjualan atas Barang Mewah (PPnBM) terhadap Daya Beli Konsumen Kendaraan Bermotor. EFISIENSI, 15(5), 132-143 
Sulaeman, S., \& Supriadi, S. (2020). Peningkatan Pengetahuan Masyarakat Desa Jelantik dalam Menghadapi Pandemi Corona Diseases-19 (Covid19). Jurnal Pengabdian UNDIKMA, 1(1), 12-17.

Sulistiawati, R. (2012). Pengaruh Investasi terhadap Pertumbuhan Ekonomi dan Penyerapan Tenaga Kerja Serta Kesejahteraan Masyarakat di Provinsi di Indonesia. Jurnal Ekonomi Bisnis dan Kewirausahaan, 3(1), 29-50.

Sulistiawati, R. (2012). Pengaruh Upah Minimum terhadap Penyerapan Tenaga Kerja dan Kesejahteraan Masyarakat di Provinsi di Indonesia. Jurnal EKSOS, 8(3), 195-211.

Syarifudin, A. S. (2020). Implementasi Pembelajaran Daring untuk Meningkatkan Mutu Pendidikan sebagai Dampak diterapkannya Social Distancing. Jurnal Pendidikan Bahasa dan Sastra Indonesia Metalingua, 5(1), 31-34.

Tojo, H., \& Takagi, A. (2017). Trends in Qualitative Research in Three Major Language Teaching and Learning Journals, 2006-2015. International Journal of English Language Teaching, 4(1), 37.

Wafirotin, K. Z., \& Marsiwi, D. (2016). Persepsi Keuntungan Menurut Pedagang Kakilima di Jalan Baru Ponorogo. Ekuilibrium: Jurnal IImiah Bidang IImu Ekonomi, 10(1), 24-36.

Yunus, N. R., \& Rezki, A. (2020). Kebijakan Pemberlakuan Lock Down Sebagai Antisipasi Penyebaran Corona Virus Covid-19. Jurnal Sosial dan Budaya Syar-i, 7(3), 227-238. 